\title{
What do China and the BRI Mean to ASEAN Economies?
}

\section{ALEXANDRA ZOLTAI \& PÉTER KLEMENSITS}

\begin{abstract}
China's Belt and Road project, announced in 2013, has had a major impact on the world, and the ASEAN countries are, of course, not an exception. However, there is no consensus among the Member States on how to manage China, and therefore the response to the BRI was not uniform, either. Some countries regard the project as a threat, others as an opportunity, but they agree that dependency on China should be kept to a minimum. However, what role this effort plays in the Belt and Road project and how feasible it is, is a major question.

The study assumed that after 2013 (inter alia thanks to the BRI), ASEANChina relations have substantially improved and economic cooperation has been strengthened. To demonstrate this, by using economic indicators, we sought to create a benchmark by which to compare the impact of China on the economies of ASEAN countries. The results show which country is economically most dependant on China and whether each country's related political narrative corresponds to the change of the economic data.
\end{abstract}

Keywords: ASEAN, China, economy, Belt and Road

\section{Introduction}

The purpose of this study was to present the relationship between the People's Republic of China (China) and the Association of Southeast Asian Nations (ASEAN) countries in the light of the Chinese Belt and Road Initiative (BRI). According to our hypothesis, the Chinese project has had a major impact on the economies of the ASEAN countries, which has also increased their economic dependence on China. In order to demonstrate this, we examined the economic relations of these countries in the year (2012) before the BRI announcement (2013), taking into account their external trade balance and FDI, and looked at the same economic indicators on the basis of the 2018 figures, which allowed us to reject or confirm the hypothesis ${ }^{1}$. Due to the elusiveness of the BRI, it is very difficult to measure the impact and dependence on individual countries. Moreover, the issue of ASEAN Member States' indebtedness to China should also be examined, but China does not issue data on this, ${ }^{2}$ so we do not have adequate sources. Due to the limited scope of this study, we only covered the relationship and economic interconnectedness of China and ASEAN countries, and only touched upon the political and economic relations with the United States of America and other major countries in the region, such as Japan, which also play a significant role. It is clear that a number of other 
factors - which mainly means geostrategic, political, and cultural considerations - also influence the impact of BRI, a reference to which was made briefly in the study as well. Unfortunately, due to the size constraints, we could not undertake to explain them in detail, although given the heterogeneity of the region, a uniform interpretation of the dependence on China regarding the individual states is a tall order. We first looked at the development of relations between China and ASEAN, and next at the Member States and the evolution of their relations with China in the light of the BRI. By analysing the economic data separately for each country and aggregating them at the end, the study provides a comprehensive comparison of the development of China's economic influence in the region before and after the BRI. We also made an attempt to examine and highlight the political links behind the development of economic relations. After the confirmation or refusal of the hypothesis, the results were used to draw conclusions on the development of the geopolitical situation in the region.

\section{Review of China-ASEAN Relations}

The relationship between ASEAN, established in 1967, and China can be divided into three stages. The initial hostile relationship was replaced by the "falling in love" era in the mid-1970s, during and after which close cooperation dominated their relations in the 1980-90s. However, from 2010, as economic interdependence increased, the relationship became more complex due to geopolitical conflicts ("phase of uncertainty") (Mahbubani \& Sng, 2017).

The ASEAN-China dialogue was established in 1991 and China became a full-fedged ASEAN dialogue partner in 1996. In 1997, the first informal ASEANChina Summit was held in Kuala Lumpur (Malaysia), during which the leaders of both sides announced their decision to establish a $21^{\text {st }}$-century-oriented, good neighbourly partnership based on mutual trust between ASEAN and China. In November 2011, the ASEAN-China Centre (ACC) was formally established. As a single-contact information and activity centre, the ACC has taken on a role in promoting cooperation between ASEAN and China in the areas of trade, investment, education, culture, tourism, information, and media. The next milestone in relations was the year 2013, when Chinese President Xi Jinping visited Indonesia and Malaysia to intensify cooperation between ASEAN and China for a better common future. In this year, the Maritime Silk Road for the $21^{\text {st }}$ century was also announced, which has a serious impact on the region and its ASEAN Member States. 2020 was designated as the ASEAN-China Year of Digital Economic Cooperation.

ASEAN and China have carried out close coordination and cooperation on international and regional issues. Both sides have jointly committed themselves to promoting a thorough development of regional cooperation in East Asia and have tackled the current and potential challenges of the region. The two parties have also maintained good communication and cooperation within the cooperation mechanisms, including the ASEAN Plus Three (China, Japan, and South Korea) Summit, the ASEAN Regional Forum, the Asia Cooperation Dialogue, the APEC, etc. 


\section{Economic and Trade Cooperation}

In November 2002, ASEAN and China signed the framework agreement on comprehensive economic cooperation, which entered into force in January 2010 and launched the process of creating the ASEAN-China Free Trade Area (ACFTA). According to the Chinese Ministry of Commerce, bilateral trade between ASEAN and China reached USD 641.46 billion in 2019, an increase of $9.2 \%$ compared to the previous year. China's exports to ASEAN amounted to USD 359.42 billion, and Chinese imports from ASEAN amounted to USD 282.04 billion, which represented an increase of $12.7 \%$ and $5 \%$, respectively. China has been the top trade partner of ASEAN for 11 years (ASEAN-China Centre, 2020). And since 2018, ASEAN has become China's second most important trading partner (ahead of the United States) after the European Union (Xilian, 2019).

According to the Chinese Ministry of Commerce, at the end of December 2019, investments between the ASEAN and China amounted to USD 236.91 billion. China's investment in ASEAN reached USD 112.30 billion and ASEAN's investment in China amounted to USD 124.61 billion. The year 2019 was the second time that ASEAN was the second largest recipient of Chinese foreign investment. ASEAN is the third largest investment source in China.

In the relations between Chine and ASEAN, tourism also plays an important role. In 2019, the total number of reciprocal visits exceeded 65 million, with around 4500 flights per week between China and ASEAN Member States (ASEAN-China Centre, 2020).

The coronavirus pandemic opened a new chapter in economic relations between the two countries, since ASEAN became China's largest trading partner in the first two months of 2020, overtaking the European Union. This has demonstrated that there is an unbreakable supply chain between Southeast Asia and China that even external shocks such as the coronavirus (Global Times, 2020) cannot tear. There is no doubt that, once the epidemic is over, the EU will take back its leading role, as it has a 2 to 3 times larger economy than ASEAN, but this shows how close the economic ties and the interdependency are between China and Southeast Asia.

\section{BRI, the New 21 $1^{\text {st }}$-Century Maritime Silk Road and the South China Sea}

In autumn 2013, China announced a global project, known as the Belt and Road Initiative, which is another step toward greater Chinese engagement in the world. This way, the Beijing leadership, following the footsteps of the former caravan trails joining Europe and Asia, committed itself to the development and modernisation of transport networks, envisioned as a China-led (funded) international development program, which also meets Beijing's geostrategic objectives by connecting remote regions to major trade routes (Klemensits, 2016). The project consists of land routes (connecting China to Central Asia, the Middle, East and Europe) and maritime routes (comprising the main commercial routes of Southeast Asia, Africa, 
Europe, and Oceania). The Belt and Road Initiative can be described as a network, which can be spatially expanded with great flexibility. China makes use of this exibility and, most recently, has extended the large-scale project with the Polar Silk Road (Zoltai, 2020). Its main concept is to link existing trade routes, reduce freight costs and increase protection, but it is also important to China because it can thus secure huge projects in the construction sector and Chinese goods can penetrate new markets. In addition to economic benefits, the initiative also has very important strategic benefits; the participating countries will become committed to China. It is therefore expected to go beyond simple Chinese-funded infrastructure developments, because its real objective is to promote regional cooperation, financial integration, free trade, and scientific cooperation (Scott, 2016). The planned investments are to be financed by the Asian Infrastructure Investment Bank and the Maritime Silk Road Bank. The Maritime Silk Road is also of great importance in diplomatic terms, and it is no coincidence that it has recently become a key element of Chinese foreign policy. According to China, infrastructure investments are not linked to political constraints, however, the interrelation of interests is indisputable. And in the case of ASEAN countries, the major strategic goal should not be forgotten either: Given the competition of China and the United States, the strengthening of Chinese influence in the region is a priority in both economic and political terms (Klemensits, 2018).

There are, therefore, serious diplomatic, economic, and strategic interests in the background. Firstly, the concept of the New Maritime Silk Road has been developed by China, inter alia, to reconcile and quiet neighbouring countries, which feel threatened by the aggressive Chinese territorial demands on the South China Sea (Yale, 2015).

Interdependence may be key to the future feasibility of the BRI. According to 2018 data, the investment in the BRI to Southeast Asia exceeded USD 740 billion. At present, 13 projects have been proven to be operational, representing a very small proportion of the projects planned in the region (Kaneti, 2020).

However, Beijing's sovereignty claims in the South China Sea, marked by the ninedash line, generates severe tensions in the region and even increases the presence of the US Navy. The situation was compounded by China's refusal to accept the 2016 ruling of the Hague's Permanent Court of Arbitration, which has thus undermined the prestige of international law (Eszterhai, V. \& Klemensits, P. 2016). China considers almost the entire South China Sea to be its own sovereign territory, which is in breach of the sovereignty of the Philippines, Vietnam, Malaysia, Brunei, and Indonesia, as these countries also have outstanding territorial demands.

\section{Cambodia}

Cambodia is considered to be one of China's main partners in the Southeast Asian region. In addition to good diplomatic relations, China has undeniably become Cambodia's largest economic partner, as it is the largest foreign investor, the largest bilateral donor, the largest trading partner, the largest buyer of Cambodian rice and also, the most tourists to the Southeast Asian country come from China. Since the 
announcement of the BRI in 2013, Cambodia has been a strong supporter of the large-scale Chinese project and has great hopes that this initiative will be one of the foundations of the nation's development. The development of infrastructure and physical connections has made significant progress in Cambodia, most of which are related to the BRI. The two most important projects are the Sihanoukville Special Economic Zone (SSEZ) and the planned Phnom Penh-Sihanoukville Expressway, (Kha, 2019), about $20 \%$ of which is currently completed (Khmer Times, 2020).

The SSEZ, in itself, has contributed to increasing employment, as more than 20,000 Cambodian employees have received jobs, and it has helped to employ low-skilled and female workers, both from Sihanoukville and other neighbouring provinces. Since trade in goods has become a driving force for growth in the country, the logistics sector is also of particular importance. At present, however, Cambodia lacks sufficient infrastructure capacity and significantly lags behind other countries in the region in logistics performance, leading to higher transport costs and seriously undermining the country's competitiveness. The implementation of the Phnom Penh-Sihanoukville Expressway could greatly improve the efficiency of the country's logistics. This new infrastructure development would modernize the connection between Phnom Penh and the port of Sihanoukville, the only international deep-sea port in Cambodia. In 2017, it accounted for more than $90 \%$ of the total container turnover in the country (Kha, 2019).

Against this background, the increasing dependence of Cambodia on China must be taken into account. The Cambodian leadership is clearly responsible for managing the BRI-related projects properly so that the Cambodian population can also benefit from it. Any excessive dependence on China imposes certain limits on Cambodia's foreign policy potential. The Cambodian elite has thus begun to move closer to China, which China has made use of, but ultimately the initiatives related to China and the BRI taken so far have benefited Cambodia. However, local criticism of these initiatives is often expressed regarding the lack of quality and transparency of Chinese investments and the low benefit for the people who live there (Kha, 2019).

In 2012, trade with China accounted for $2.17 \%$ of Cambodia's total exports and $22.3 \%$ of its imports. In 2018, exports increased to $6.92 \%$ and imports to $25.1 \%$ between the two countries. Between 2012 and 2018, China was the second fastest growing export market (+ 413\%) and the third fastest growing import market $(117 \%)$ for Cambodia (OEC. Cambodia). In 2018, 19.6\% of all FDI in Cambodia was from OFDI from China (Zhōnghuá rénmín gònghéguó shāngwù bù, 2018).

\section{Myanmar}

There is an interdependence between Myanmar and China on security issues. When the international community imposed sanctions against Myanmar for violations of human rights and isolated the country, the regime, which had been seized with military support, received support from China to ensure its survival, so that China could become the international ally of the military junta in Myanmar. In addition, China was the main source of military equipment and training for Myanmar, while 
China needed Myanmar's cooperation to enforce its own security interests. China is building port facilities in Myanmar, which are of strategic importance in its access to the Indian Ocean (Chen, 2019).

In January 2020, Xi Jinping made an official visit to Myanmar on the occasion of the $70^{\text {th }}$ anniversary of diplomatic relationship between the two countries, and they also strengthened bilateral cooperation. Xi Jinping's visit focused mostly on the Kyaukphyu Special Economic Zone (SEZ) and the deep-sea port. The agreements signed during the visit include a railway line linking the Chinese Kunming (Yuannan Province in southern China) to Kyaukphyu touching Muse and Mandalay, which are located in the northern and middle part of Myanmar, as well as the new Yangon City project developed by the China Communications Construction Company (CCCC). The projects are all linked to the China-Myanmar Economic Corridor (CMEC), which is part of the Chinese BRI. Myanmar is of particular importance to Beijing's geostrategic plans; the country provides China access to the Indian Ocean. The Indian Ocean offers significant shipping routes to China to import oil from the Middle East. Land routes are already in use, the Kyaukphyu pipelines have been transporting gas from Myanmar all the way to Kunming since 2013 and oil since 2017, allowing Beijing to avoid the South China Sea and the strategically vulnerable Malacca Strait.

Myanmarese State Counsellor Aung San Suu Kyi recognized the need to accelerate economic growth in her country and to develop the necessary infrastructure, and therefore agreed to the implementation of the China-Myanmar Economic Corridor connecting Kyaukphyu and Kunming at a meeting with Xi Jinping in Beijing in 2017. Myanmar's leadership has a strong sympathy with the Chinese Communist Party and favours Chinese companies to accelerate economic growth in Myanmar and improve its underdeveloped infrastructure (Marston, 2019).

Outside ASEAN, China, India, Japan, and South Korea have also increased their bilateral trade flows with Myanmar and China has become its main trading partner. Although Thailand remains the largest destination for Myanmarese exports, China has been its largest foreign partner since 2011. Data recorded in 2012 show that $37.7 \%$ of the total Myanmarese imports came from China, while $15.8 \%$ of its total export flowed into China. In 2018, $24.7 \%$ of Myanmarese exports were destined for China, which made China the second largest destination for Myanmarese exports after Thailand. China accounted for $39.6 \%$ of the total Myanmarese imports with a slight drop, but still ahead of Thailand (17.2\%). As a result, Myanmar's domestic consumption continues to rely heavily on products and services originating in China. Between 2012 and 2018, China was the fastest growing export (+301\%) and import market (+89.4\%) (OEC. Myanmar). In 2004, the Chinese FDI in Myanmar accounted for only $1.9 \%$ of China's total foreign investment. However, following the imposition of economic sanctions by Western countries in the early 2000s against the leadership which was declared to be repressive, China started to make significant investments in Myanmar and became the largest foreign investor by 2011. In 2018, Chinese OFDI in Myanmar already accounted for $14.9 \%$ of all of its foreign investment (Zhōnghuá rénmín gònghéguó shāngwù bù, 2018). 


\section{Laos}

Laos is one of the smallest and poorest countries within ASEAN. Approximately $61 \%$ of its 6.8 million inhabitants are of working age, so the country is a popular target for labour-intensive industries. Export and tourism are the main drivers of the country's economic growth, but its trade volume is rather small and its main trading partners are its immediate neighbours: Thailand, China, and Vietnam (Wroblel, 2019).

China and Laos established diplomatic relations in 1961, but the tensions between the two countries remained during the Cold War. Rapprochement only occurred in the 1990s and 2000s, and the countries' relations reached the level of a comprehensive strategic partnership in 2009. There are still many conflicts in the relations between the two countries (whether it be local dissatisfaction with particular Chinese infrastructure projects or the concern that Vientiane is too reliant on Beijing), but bilateral cooperation is still developing.

One of the most important initiatives between the two countries is currently the railway project between China and Laos, which, once completed, will be the longest railway line in Asia located outside China. The project is a $414 \mathrm{~km}$ railway line from the town of Boten on the Laos-China border to Vientiane. Trains will be able to run at a speed of $160 \mathrm{~km} / \mathrm{h}$ on the line, which includes $198 \mathrm{~km}$ of tunnels and $62 \mathrm{~km}$ of bridges. Of course, the whole project is part of the BRI, the main objective of which is to channel the landlocked country into trade and transform it into a continental hub. The project started in 2016 and is expected to be completed by the end of 2021 (Parameswaran, 2020). As Laos is a rather poor country with limited natural resources, it is highly vulnerable to the Chinese initiative (Lintner, 2019).

Trade with Thailand dominates the foreign economy of Laos: in $2018,51.2 \%$ of its export flows to Thailand, while $66.9 \%$ of its import comes from there. Second, however, is China, representing $31.7 \%$ of exports and $22.6 \%$ of imports in the total Lao trade. China's share grows more year by year compared to that of Thailand, but the difference is still significant. Between 2012 and 2018, the second fastest growing export $(+117 \%)$ and import market $(+48.9 \%)$ was China after Thailand (OEC. Laos). In 2010, it preceded Thailand as the largest foreign investor. In 2003 , the Chinese OFDI amounted to $1.5 \%$ of all FDI in Laos. In 2012, however, it increased to $58.8 \%$ and in 2018 to $87 \%$ of the total Lao FDI (Zhōnghuá rénmín gònghéguó shāngwù bù, 2018). The figures show that Laos is highly dependant on China, which, on the one hand, places the country in a difficult situation and, on the other hand, represents a potential for Lao development.

\section{Vietnam}

China's relationship with Vietnam is greatly influenced by their history and the South China Sea, which is still a source of conflict. However, Vietnam is in favour of the BRI Initiative, yet cautious about the related Chinese loans. There are several factors involved: for example, mistrust toward Beijing and the strategic consequences of 
debt to China for the South China Sea dispute as well as unfavourable conditions for Chinese loans. Vietnam's participation in the BRI is therefore rather modest and slow, although the country is in dire need of infrastructure development. The first infrastructure project under the BRI Initiative is the Cat Linh-Ha Dong metro line in Hanoi, which has been under construction since October 2011 and subsequently recognized as part of the BRI by both parties. The total construction is worth USD 552 million, of which USD 419 million is provided by the Chinese Eximbank. In the meantime, the investment cost has almost doubled, and China has granted new loans. Xi Jinping's visit to Vietnam in 2017 led to an agreement to support the "Two Corridors, One Belt" (TCOB) initiative and thus the BRI. The main objective of the initiative is to provide better rail connection between China and Vietnam (Hiep, 2018).

Vietnam's budget deficit remains high, which means that investment in statefunded infrastructure projects is still not expected, and therefore the country remains interested in the BRI. It is likely to participate in pilot projects, but for fear of increasing public debt, it will rather encourage private investors to take out loans. Given the relationship between the two countries, there is no doubt that the BRI will face significant challenges in Vietnam; for example, if the South China Sea dispute intensifies, Vietnam will become more sensitive to the political and strategic consequences of the BRI. However, if the situation continues to be peaceful, there is a great chance of a stronger commitment from Vietnam (Hiep, 2018).

This also shows that Vietnam seems to be trying to avoid economic dependence on China. However, it is becoming less and less able to do so with regard to imports. In 2012, trade with China accounted for $11.3 \%$ of Vietnam's total exports and $25.3 \%$ of its imports. In 2018, exports increased to $19.6 \%$ and imports to $32.9 \%$ between the two countries. Between 2012 and 2018, China was the fastest growing export $(+271 \%)$ and import market $(174 \%)$ for Vietnam (OEC. Vietnam). In 2012, Chinese FDI amounted to USD 1.6 billion in Vietnam, while by 2018, it was almost four times higher, increasing to USD 5.6 billion. In 2018, 3.8\% of all FDI in Vietnam was from Chinese OFDI, thus the country tries to remain independent from China in terms of foreign direct investments (Zhōnghuá rénmín gònghéguó shāngwù bù, 2018).

\section{Thailand}

During the financial crisis in Asia, the relationship between China and Thailand has continued to grow and intensify due to economic cooperation. However, since $\mathrm{Xi}$ Jinping's assuming of power, the anti-Chinese voices in the country have become stronger. In particular, the younger generation was disappointed with the leadership taking office in 2014, when they became too committed to China, and public opinion is rather sceptical about the Thai-Chinese railway agreement and its bad interest rate conditions, which cause serious concerns about drifting into a debt trap. Thailand's economy is highly dependant on Chinese tourists, which also causes disapproval from local people (Bunyavejchewin, 2020). 
The railway project under the BRI Initiative would link Bangkok to Nong Khai, located in the North of Thailand, by high-speed rail technology imported from China. This would make it possible to reach China and Kunming through Laos. Therefore, the construction of the Thailand-China high-speed railway line is a priority project within the BRI, and the connection with the capital of Laos, Vientiane, would also be crucial to Thailand's economy, as it would reduce trade costs. On the basis of the preliminary negotiations, it appears that the project will have a moderate impact on Thailand's debt. The Thai Government is going to spend USD 5.8 billion for the first phase of the project, which will cover roughly half of the line's costs (estimated at USD 9.9 billion based on 2017 figures, accounting for 2\% of Thailand's economy). However, the funding proposed by the Thai Government seems to be rather careful and prudent, with at least $80 \%$ of the project being funded from internal sources in Thai baht and the remaining $20 \%$ in US dollars from external debt (Lam, 2019).

Thailand is the second largest economy in ASEAN, and unlike domestic fears, its economy is quite balanced. In 2012, trade with China accounted for $13.1 \%$ of Thailand's total exports and $15.4 \%$ of its imports. In 2018, exports fell to $11.8 \%$ and imports increased to $20.1 \%$ between the two countries, and in the same year, China was Thailand's main trading partner in both respects. Between 2012 and 2018, China was the fastest growing import market $(+26.3 \%)$ for Thailand (OEC. Thailand). In $2018,2.6 \%$ of all FDI in Thailand was from Chinese OFDI, thus the country tries to remain independent from China in terms of foreign direct investments (Zhōnghuá rénmín gònghéguó shāngwù bù, 2018).

\section{Indonesia}

The development of Indonesian-Chinese relations started from the end of the Cold War, since the Suharto Government only established diplomatic relations with China in 1990. However, economic and political cooperation remained limited until the late 2010s. Regarding the Maritime Silk Road, for China, the archipelagic state is the most important Southeast Asian country for geostrategic and geo-economic reasons. Besides the Malacca Strait, both the Lombok Strait and the Sunda Strait allow the largest country in the region to control the strategically important maritime trade routes along which most of the Chinese export-import passes. Therefore, it can be stated that without Indonesia's participation, the whole initiative would fail (Parameswaran, 2018). However, the Indonesian and the Chinese governments soon agreed: according to President Joko Widodo's (Jokowi) concept, he aspired to turn his country into a "Global Maritime Fulcrum" between the Pacific and the Indian Ocean, and Chinese plans are completely adapted to this idea. Although Indonesia is the world's biggest archipelago, the infrastructure is deeply underdeveloped. The government lacks sufficient financial resources and hopes that China will provide them (in the form of loans and aid). Presently Indonesia is the biggest economy in ASEAN and by 2030 it is projected to be the $7^{\text {th }}$ biggest economy in the world; hence the bilateral relationship is especially important to China. 
In November 2014, President Jokowi pledged himself "to improve Indonesia as a trade nation through the construction and upgrading of its maritime infrastructure, including 24 strategic ports and five deep-sea ports." (Duquennoy Zielonka, 2015). The aim is to boost Indonesia's connectivity, trade opportunities, and attractiveness for foreign investments. China correctly realised that it is an enormous business opportunity, since Jakarta wants to build these facilities all over the country in the near future, mainly with the help of Chinese companies. The joint Indonesian-Dutch-Chinese development of the Kuala Tanjung port started in 2015 (at a cost of USD 2.5 billion), during which the construction of the multipurpose terminal, industrial zone, and container port has already been completed, while the integrated industry zone connected to the port is expected to be completed by 2023 (Gunawan, 2019). A flagship project of the BRI, the $150 \mathrm{~km}$ long Jakarta-Bandung high-speed railway (costing USD 5.9 billion), is expected to be completed by 2021 (CSIS, 2020) from the Chinese loan. Besides the development of the Lembeh International Airport, construction of the Kayan River Hydropower Plant has also begun. The development of tourism has also received priority attention: In the West of Java, covering 3000 ha, the MNC Lido City, a commercial, residential, entertainment, and leisure complex is being built. And in North Sumatra, next to Lake Toba, a Tourism District, comprising 10 villages, is currently being established (Parama, 2020). The investments are part of the Regional Comprehensive Economic Corridor, which comprise North Sumatra, North Kalimantan, North Sulawesi and Bali.

The development of economic relations is well reflected by the fact that China has been Indonesia's largest trading partner for nine years now. The most tourists also come from China (an average of 2 million people per year). In 2012, 15.1\% of Indonesian exports were destined for Japan, with China in second place by 12.3\%. China took the lead in 2018 with $14.3 \%$, while Japan returned to the second position with $10.3 \%$. As far as imports are concerned, China was the main partner already in 2012 with $15.9 \%$, increasing to $24.3 \%$ by 2018 . Thanks to this, China was the fastest growing import market (+45.7\%) between 2012 and 2018 (OEC. Indonesia). In 2018, the country received Chinese investments worth USD 1.86 billion, meaning that $5.7 \%$ of all FDI in the country was from Chinese OFDI (Zhōnghuá rénmín gònghéguó shāngwù bù, 2018).

\section{Malaysia}

Malaysia was the first ASEAN country to diplomatically engage with China in 1974, and the Malaysian governments considered close cooperation with Beijing to be a priority. Under the Prime Ministry of Najib Tun Lazak (2009-2018), the country has made a firm commitment to the BRI, and Chinese projects have been expected to significantly benefit the economy. In the framework of this, an agreement has been concluded on the establishment of the Malaysia-China Kuantan Industrial Park, as a result of which China implemented infrastructural investments in the port of Kuantan, located on the eastern shore of the Malaysian Peninsula. 
Malaysia's first industrial park, which has been granted national status, was built on $685 \mathrm{ha}$, and mainly hosts the steel, electronics, communication technology, and renewable energy industry (MCKIP, 2020).

In 2014, the Malacca Gateway Project, which is largely financed by Chinese companies, was launched, which includes the establishment of a vital deep-water port in the Strait of Malacca. The Malacca industrial park is also one of the main components of the project. Within this framework, the aim is to build 3 reclaimed artificial islands and develop one natural island for touristic purposes, with the exception of Pulau Melaka, which has to become a maritime activities centre (FMT News, 2017). One of the most ambitious BRI projects in Southeast Asia has since been significantly delayed, even though it received the green light from the new Malay Government in 2019.

Following the change of government in 2018, Mahathir bin Mohamad suspended the ongoing BRI projects, notably the East Coast Railway Line, the Multi-Product Pipelines, and the Trans-Sabah Gas Pipelines, on the grounds of the country's difficult economic situation. The $640 \mathrm{~km}$ long East Coast Railway Line aims to establish communication between the East and the West of Malaysia, which is also of vital interest to China in order to avoid the Malacca Strait. Once the conditions have been renegotiated (Malay companies were granted a $40 \%$ share of the construction and the total costs have been reduced to USD 10.7 billion), Mahathir's Government revived the project in 2019, which is expected to be completed by 2026 (Railway technology, 2020). Mahathir has also expressed support for the Bandar Malaysia project, which is a mixed-use, transit-oriented development (TOD) in the capital city. The project is located at the terminus of a new high-speed rail line, which, when completed, will connect Kuala Lumpur to Singapore. The development affects an area of 196.7 ha and costs as much as USD 33.6 billion. The Forest City project, being built from a USD 100 billion investment, will also continue. It aims to establish a city quarter in the Johore Strait opposite Singapore, covering an area of $30 \mathrm{~km}^{2}$, which would include commercial, industrial, and residential buildings, ensuring the livelihood of 700,000 people (Clark, 2020).

Malaysia is the world's $35^{\text {th }}$ largest economy in terms of GDP, and China is a very important partner. In 2012, $15.5 \%$ of Malaysian exports were destined for China, while $15.9 \%$ of imports came from there. In 2018, China's share of Malaysian exports decreased to $13.4 \%$, while its share of imports increased to $21.2 \%$. Between 2012 and 2018, China was the fastest growing import market $(+46.1 \%)$ for the country (OEC. Malaysia). In 2018, 5.4\% of all FDI in Cambodia was from OFDI from China (Zhōnghuá rénmín gònghéguó shāngwù bù, 2018).

\section{Philippines}

The Philippines, under President Rodrigo Duterte's Presidency from 2016, realized that the improvement of economic relations with China was of strategic importance. Duterte started to form his new, admittedly "independent" foreign policy, which - in contrast with his predecessor, President Benigno Aquino - 
has totally redefined the country's foreign and security policy strategy, the most striking aspect of which is its turning from the United States and opening towards China. Duterte tries to establish good relations with both the rival major powers, and he would not like to relinquish the US investments either, but whereas these have not been able to meet even the infrastructural needs, it is clear that there is a need to look for new partners. China's positive attitude paved the way for Duterte's official visit to the country, held between October 18 and 21. It is no coincidence that he was accompanied in his visit to Beijing by more than 400 businessmen: the improvement of economic relations was of key importance. Finally, 21 different agreements have been signed in total, worth USD 24 billion, of which USD 15 billion is Chinese investment, together with a credit facility of USD 9 billion (Calonzo \& Yap, 2016).

The country would not like to be excluded from China's $21^{\text {st }}$-century Maritime Silk Road Project, therefore, most of the investments are infrastructural developments. In November 2018, the government announced that 12 of the 35 flagship projects would be implemented from Chinese loans and aid. At that time, the first round of projects included the pump station to be built on the Chico river (2.7 billion peso); the Kaliwa Dam (10.9 billion peso); a railway project (151.3 billion peso); and the Binondo-Intramuros and Estrella-Pantaleon bridges (Padin, 2018).

The second round of investments are planned to include: The first phase of the Safe Philippines project; the Subic-Clark railway; 5 bridges over the PasigMarikina River and the Manggahan Canal; and the drainage projects of the Rio Grande de Mindanao river (De Vera, 2018). Most recently, in October 2019, the two parties agreed on the details of financing the Panay-Guimaras-Negros Bridge and the Davao high-speed rail. According to the Duterte Government, the country's participation in the New Maritime Silk Road initiative of the $21^{\text {st }}$-century will clearly improve the international competitiveness of the country, as infrastructure improvements will reduce the cost of trade with China, as well as Europe, the Middle East, and Africa. New markets will open up to Philippine industry and agriculture, while millions of new jobs are created. However, despite the spectacular plans, very few projects have reached the implementation phase by 2020 . Red tape, resistance of the military circles, caution on the Chinese side, environmental concerns, or even fear of a debt trap have slowed the majority of investments, or, in some cases, even shut them down temporarily or definitively.

After Indonesia and Thailand, the Philippines has the third largest economy in ASEAN, with a stable annual GDP growth of over $6 \%$ in recent years. By 2019 , China became the largest trading partner of the Philippines and one of the most popular tourist paradises (Xinhua, 2019). In 2012, the country conducted $23.4 \%$ of its exports with China (the largest export market), which decreased to $13.6 \%$ by 2018, while it must be noted that the largest export market has become Hong Kong $(14.2 \%)$. As far as imports are concerned, China was the main partner already in 2012 with $12.7 \%$, increasing to $24 \%$ by 2018. Between 2012 and 2018, China was the fastest growing import market (+238\%) (OEC. Philippines). However, contrary to government plans, Chinese investment in the country has not increased significantly: In 2018, only 1\% of all FDI was from Chinese FDI (Zhōnghuá rénmín gònghéguó shāngwù bù, 2018). 


\section{Singapore}

The Malacca Straits and Singapore are of strategic significance, but due to the power of the city-state, Chinese influence may be considered minimal here. Nevertheless, China also committed itself to Singapore to strengthen the cooperation. In 2016, considerable progress was made in this respect since, according to the agreement between the China Construction Bank Corporation and International Enterprise Singapore, USD 21 billion were allocated to support infrastructure projects (China Daily, 2016). Singapore has favoured the BRI from the outset, focusing in particular on infrastructure, financial connectivity, and investment in third countries. In April 2019, the two parties signed an extended agreement on e-commerce, logistics, and professional services, while creating a USD 500 million financial fund for infrastructure development in Southeast Asia (Wei, 2019). In order to improve land connectivity, Singapore and Malaysia started building the $350 \mathrm{~km}$ long Kuala Lumpur-Singapore high-speed railway worth USD 11 billion in 2017, which is scheduled to start operating in 2031 (Railway technology, 2020). The BRI project is part of the planned KunmingSingapore railway line. Despite the positive attitude of the government, some consider that the $21^{\text {st }}$-century New Maritime Silk Road could lead to the loss of the formerly unique shipping hub nature of the Singapore port, as China's improvements in Malaysia and the land routes could cause a decrease in trade ows.

China is Singapore's largest trading partner, while the city-state is China's largest foreign investor. In 2012, Hong Kong was still the main destination for exports from Singapore with $12.4 \%$, while China was the second destination with $10.9 \%$. In 2018 , most of Singapore's exports were already directed to China with $13.7 \%$ and Hong Kong was second place with $12.9 \%$. As far as imports are concerned, China had a share of $10.8 \%$ as the largest partner in 2012 , which increased to $14.6 \%$ by 2018 . Between 2012 and 2018, China was the fastest growing export market (+43.4\%) for Singapore (OEC. Singapore). In 2018, China held a 3.3\% share of the country's FDI stock (Zhōnghuá rénmín gònghéguó shāngwù bù, 2018). In this year, the city-state was the largest foreign investment destination for China along the BRI, capturing close to $23 \%$ of the total investment outflow from China to Belt and Road countries (Wei, 2019).

\section{Brunei}

The Sultanate is primarily linked to China by economic ties, since Brunei is strongly in favour of the BRI project, and China has also promised assistance in diversifying its economy. The Brunei economy is essentially based on oil and gas extraction, but the depletion of stocks may cause serious problems in the future and low oil prices have already led to a recession. However, the investment in infrastructure offered by China and the increase in trade flows can be a solution to the problems. One of the largest BRI projects, the construction of an oil refinery started in 2017 by Hengyi Industries and Brunei's partner, with a total cost of USD 3.4 billion, was completed in 2019. The other project, the Brunei-Guangxi Economic Corridor, which includes investment of nearly USD 500 million, is aimed at the reconstruction of the Muara port and the creation of an agricultural and medical park. Within this framework, 
in 2017, a joint venture company formed by China's Guangxi Beibu Gulf Port Group and Brunei's Darussalam Asset took over the operation of Muara Container Terminal, the largest container terminal in the country (China Daily, 2017).

In recent years, economic relations between the two countries have been considerably strengthened. In 2012, Japan accounted for $45.1 \%$ of Brunei's exports, while China represented $2.58 \%$. In 2018, although Japan's predominance decreased (33.2\%), China's share increased to only $3.76 \%$. As for imports, in 2012, China followed after Singapore and Malaysia with $11 \%$, but in 2018 it became the top partner, with 33.9\%. Between 2012 and 2018, China was the fastest growing import market (+191\%) for Brunei (OEC. Brunei). In 2018, 3.3\% of all FDI in Brunei was from Chinese OFDI, thus the country is still largely independent from China in terms of foreign direct investments (Zhōnghuá rénmín gònghéguó shāngwù bù, 2018).

\section{Conclusion}

In light of the above, our hypothesis has been proven, namely that the BRI has had a serious impact on the economies of ASEAN countries, which has also led to an increase in their economic dependence on China. However, the data also show that there are significant differences between countries due to geographical, geostrategic, economic, and cultural reasons. In mainland Southeast Asia, the economies of Cambodia, Laos, and Myanmar are heavily dependant on China, but in Thailand and Vietnam, despite the growing position of China in the areas of external trade and FDI, the efforts of the latter states to balance themselves between the major powers and preserve their distance from Beijing are considered effective. Looking at the Pacific, it can be concluded that in the case of Indonesia, Malaysia, and the Philippines, their economic relations with China have become increasingly strong - the fluctuation of political relations set aside -, manifested mainly in the volume of BRI projects and the shift in external trade balance. In Singapore's and Brunei's relations with China, this trend is also observed, while the economic benefits for the latter are more apparent than for the other countries. The strengthening of economic relations between ASEAN states and China also has significant geopolitical consequences, the most prominent aspect of which is the strengthening of Chinese influence, together with the decline of US power in the region.

\section{Bibliography}

ASEAN-China Centre. (2020). ASEAN-China relations. Retrieved from http://www. asean-china-center.org/english/2020-03/4613.html

Bunyavejchewin, P. (2020). Will the 'Milk Tea War' Have a Lasting Impact on China-Thailand Relations? The Diplomat, Retrieved from https://thediplomat. com/2020/05/will-the-milk-tea-war-have-a-lasting-impact-on-china-thailandrelations/ 
Calonzo, A. \& Yap, C. (2016). China Visit Helps Duterte Reap Funding Deals Worth $\$ 24$ Billion. Bloomberg. Retrieved from https://www.bloomberg.com/news/ articles/2016-10-21/china-visit-helps-duterte-reap-funding-deals-worth-24-billion

Chen, I. T. (2019). China's Economic Offensive and Its Discontent in Southeast Asia: Diminishing Footprints in Myanmar. In: Diokno, M. S. I., Hsiao, \& Yang, H.M. (Eds.), China's Footprints in Southeast Asia. (pp. 63-89.) Singapore: NUS Press.

China Daily (2017). China-Brunei joint venture starts operating Brunei's container terminal. Retrieved from http://www.chinadaily.com.cn/business/2017-02/22/ content_28300108.htm

China Daily. (2016). Singapore, China enhance cooperation under Belt and Road Initiative. Retrieved from http://usa.chinadaily.com.cn/business/2016-12/22/ content_27742191.htm

Clark, J. (2020). Forest City Malaysia - A new city on man-made islands near Singapore. Retrieved from https://ivinginasia.co/forest-city/

CSIS. (2020). Jakarta-Bandung High-Speed Rail (PPP). Retrieved from https:// reconnectingasia.csis.org/database/projects/jakarta-bandung-high-speed-railppp/7c6cb573-6aa1-4844-b5fd-113d2488bbef/

De Vera, B. O. (2018). PH, China to sign 10 infrastructure loan agreements in November - Diokno. Inquirer.net, Retrieved from https://business.inquirer. net/256322/ph-china-sign-10-infrastructure-loan-agreements-november-diokno

Duquennoy, A. \& Zielonka, R. (2015). Bridging Asia and Europe Through Maritime Connectivity. Retrieved from http://www.eias.org/wp-content/uploads/2016/02/ Bridging_Asia_Europe_2015.pdf

Eszterhai, V. \& Klemensits, P. (2016). A dél-kínai-tengeri szigetek ügyében hozott hágai ítélet geopolitikai következményei. PAGEO Policy Brief. Retrieved from http://www.geopolitika.hu/hu/2016/08/04/pageo-policy-brief-i-del-kinai-tenger/

FMT News. (2017). Malaysia key player in China's Belt and Road Initiative. Retrieved from http://www.freemalaysiatoday.com/category/nation/2017/01/11/malaysiakey-play-in-chinas-belt-and-road-initiative/

Global Times. (2020). ASEAN becomes China's largest trading partner. Retrieved from https://www.globaltimes.cn/content/1181864.shtml

Gunawan, A. (2019). Dutch and Chinese operators to help expand Kuala Tanjung port. The Jakarta Post. Retrieved from https://www.thejakartapost.com/news/2019/11/22/ dutch-and-chinese-operators-to-help-expand-kuala-tanjung-port.html

Hiep, L. H. (2018). The Belt and Road Initiative in Vietnam: Challenges and Prospects. ISEAS Perspective. Retrieved from https://think-asia.org/bitstream/ handle/11540/8138/ISEAS_Perspective_2018_1850.pdf?sequence=1

Hunter, M. (2019). Has the US Lost Myanmar to China? The Diplomat, Retrieved from https://thediplomat.com/2020/01/has-the-us-lost-myanmar-to-china/

Kaneti, M. (2020). ASEAN Must Make the Best of Its New Centrality in China's Diplomacy. The Diplomat. Retrieved from https://thediplomat.com/2020/06/ asean-must-make-the-best-of-its-new-centrality-in-chinas-diplomacy/ 
Kha, S. (2019). The Belt and Road in Cambodia: Successes and Challenges. The Diplomat. Retrieved from https://thediplomat.com/2019/04/the-belt-androad-in-cambodia-successes-and-challenges/

Khmer Times (2020). Billion-dollar highway to Sihanoukville 20pct ready. Retrieved from https://www.khmertimeskh.com/697727/billion-dollarhighway-to-sihanoukville-20pct-ready/

Klemensits, P. (2016). Az óceánok új felfedezői: Kína és a 21. századi új Tengeri selyemút. Retrieved from http://www.geopolitika.hu/hu/2016/12/15/az-oceanokuj-felfedezoi-kina-es-a-21-szazadi-uj-tengeri-selyemut/

Klemensits, P. (2018). Geopolitical Consequences of the $21^{\text {st }}$ Century New Maritime Silk Road for the Southeast Asian Countries. Contemporary Chinese Political Economy and Strategic Relations 4(1), 129.

Lam P. D. (2019): Will Thailand's Chinese High-Speed Railway Be Worth It? The Diplomat. Retrieved from https://thediplomat.com/2019/03/will-thailands-chinabuilt-railway-be-worth-it/

Lintner, B. (2019). China-Laos friendship 'blossoming. Asia Times. Retrieved from https://asiatimes.com/2019/04/china-laos-friendship-blossoming/

Mahbubahni, K., Sng J. (2017). The ASEAN miracle. A catalyst for peace. Singapore: NUS Press.

MCKIP, (2020). Malaysia-China Kuantan Industrial Park. Retrieved from http://www. mckip.com.my/

OEC. Cambodia. Retrieved from https://oec.world/en/profile/country/khm

OEC. Brunei. Retrieved from https://oec.world/en/profile/country/brn

OEC. Indonesia. Retrieved from https://oec.world/en/profile/country/idn

OEC. Laos. Retrieved from https://oec.world/en/profile/country/lao

OEC. Malaysia. Retrieved from https://oec.world/en/profile/country/mys

OEC. Myanmar. Retrieved from https://oec.world/en/profile/country/mmr

OEC. Philippines. Retrieved from https://oec.world/en/profile/country/phl

OEC. Singapore. Retrieved from https://oec.world/en/profile/country/sgp

OEC. Thailand Retrieved from https://oec.world/en/profile/country/tha

OEC. Vietnam Retrieved from https://oec.world/en/profile/country/vnm

Padin, M. G. (2018). Philippines to sign 2 big-ticket infrastructure project with China. PhilStar. Retrieved from https://www.philstar.com/business/2018/11/01/1864805/ philippines-sign-2-big-ticket-infrastructure-project-china

Parama, M. (2020). Govt begins construction of Lake Toba tourism villages. The Jakarta Post. Retrieved from https://www.thejakartapost.com/news/2020/07/13/ govt-begins-construction-of-lake-toba-tourism-villages.html

Parameswaran, P. (2018). China's Belt and Road in Southeast Asia between Boons and Bumps. The ASAN Forum. Retrieved from http://www.theasanforum.org/ chinas-belt-and-road-in-southeast-asia-between-boons-and-bumps/ 
Parameswaran, P. (2020). China-Laos Relations in Focus with New Railway Project Milestone. The Diplomat, Retrieved from https://thediplomat.com/2020/03/chinalaos-relations-in-focus-with-new-railway-project-milestone/

Railway technology. (2020). East Coast Rail Link (ECRL) Project, Malaysia. Retrieved from https://www.railway-technology.com/projects/east-coast-rail-link-ecrl-project/

Railway technology. (2020). Kuala Lumpur-Singapore High Speed Rail. Retrieved from https://www.railway-technology.com/projects/kuala-lumpur-singapore-highspeed-rail/

Scott, R. (2016). China's Maritime Silk Road Project Advances. Hellenic Shipping News. Retrieved from http://www.hellenicshippingnews.com/chinas-maritime-silkroad-project-advances/

The Economist (2020). The poorest countries may owe less to China than first thought. Retrieved from https://www.economist.com/finance-and-economics/2020/07/04/ the-poorest-countries-may-owe-less-to-china-than-first-thought

Wei, T. D. (2019). Singapore, China ink deals on trade, BRI. Straits Times. Retrieved from https://www.straitstimes.com/asia/east-asia/singapore-chinaink-deals-on-trade-bri

Wrobel, R. M. (2019). Chinese Geopolitics in Southeast Asia: A New Pattern of Economic Power within ASEAN? Asia 73(1). 170-172.

Xilian, H. (2019). New era for China-ASEAN relations. China Daily. Retrieved from https://www.chinadaily.com.cn/a/201910/10/WS5d9e9db0a310cf3e3556fac6.html

Xinhua, (2019). Philippines reaping economic benefits from harmonious ties with China: Finance chief. China.org.cn Retrieved from http://www.china.org.cn/ business/2019-11/26/content_75448039.htm

Yale, W. (2015). China's Maritime Silk Road Gamble. The Diplomat. Retrieved from https://thediplomat.com/2015/04/chinas-maritime-silk-road-gamble/

Zhōnghuá rénmín gònghéguó shāngwù bù [People's Republic of China Ministry of Commerce] (2018). 2018 Zhōngguó duìwài zhēn jiē tóuzī tǒngjì gōngbào [2018 Statistical Bulletin of China's Outward Foreign Direct Investment].

Zoltai, A. (2020). Kína geopolitikai és geoökonómiai stratégiája az északi-sarkon: új régiós hatalom a láthatáron? In: Geopolitikai Szemle, II. évfolyam 2020/1. No4. 183-202.

\section{Endnotes}

1 The data relating to China exclude Hong Kong.

2 As a result of the crisis caused by the coronavirus, at the initiative of the World Bank, the world's 73 poorest countries' debt towards each country has been made public in order to help developed countries manage their debt. However, only Cambodia, Myanmar, and Laos belong to this group, so a full comparison cannot be made and no data were provided before 2019. (The Economist, 2020). 